\title{
Teesside coronary survey: an epidemiological study of acute attacks of myocardial infarction
}

\author{
AUBREY COLLING, ALEXANDER W DELLIPIANI, RAYMOND J DONALDSON, \\ PETER MACCORMACK
}

premonitory symptoms; and the fatality rates of patients treated at home and in hospital.

\section{Summary}

A 12-month epidemiological survey of attacks of acute myocardial infarction was carried out in a large urban population. The incidence and mortality at all ages and in both sexes were examined. Altogether, 1938 attacks were diagnosed-an overall incidence of 4.89 per 1000 population. The 28-day fatality rate was $50.5 \%$. A third of the patients were treated at home and these patients had a lower fatality rate than those in hospital, a difference that could not be attributed to age, sex, or severity of attack. Half of the deaths that were witnessed occurred suddenly and a further $21 \%$ occurred within the next two hours. The median time to patients coming under care was about three hours.

As used at present, coronary care units are unlikely to improve fatality rates. Future advances in treatment must take place outside hospital and will require reeducation of the public and the general practitioner.

\section{Introduction}

In 1970 we decided to assess the potential benefit of a mobile coronary care unit in Teesside by making an epidemiological survey of attacks of acute myocardial infarction. Surveys in Edinburgh $^{1}$ and Oxford ${ }^{2}$ had shown a great difference in the incidence of myocardial infarction, but they lacked information about older people. Other reports, such as those from Bristol, ${ }^{3}$ Belfast, ${ }^{4}$ and Doncaster, ${ }^{5}$ although valuable, were of limited help in planning a community service. A survey in east London ${ }^{6}$ was also age restricted and few cases were managed at home.

Our main objectives were to determine the incidence, mortality, and fatality of attacks of acute myocardial infarction; the time and place of these attacks; the schedule of events leading to patients coming under care; and interval between onset of attacks and death; the frequency and relevance of

Stockton, Cleveland

AUBREY COLLING, MD, FRCGP, general practitioner

North Tees General Hospital, Stockton, Cleveland

ALEXANDER W DELLIPIANI, MD, FRCP, consultant physician

\section{Teesside}

RAYMOND J DONALDSON, MB, DPH, medical officer of health Teesside (now senior lecturer, London School of Hygiene and Tropical Medicine, London WC1)

General Hospital, Middlesbrough, Cleveland PETER MACCORMACK, MRCP, consultant physician

\section{Methods}

We collected data on every suspected attack of myocardial infarction reported in Teesside from 5 April 1972 to 4 April 1973. The 396000 people of Teesside County Borough were served by 150 general practitioners and 10 consultant physicians working in 14 hospitals, two of which had coronary care units.

We made exhaustive efforts to ensure that every suspected attack of myocardial infarction was notified. A simple notification procedure was established which depended on an exclusive telephone with a 24-hour answering service. Family doctors, consultant physicians, industrial medical officers, nurses attached to family doctors and the emergency medical service all co-operated. Death certificates were also scrutinised.

When possible information was obtained from the patient. Four nurses were employed full-time and trained for the project. A survey nurse visited the patient soon after notification and collected, in a standard way, personal details of job, age, history, premonitory symptoms, smoking habits, and timing of events. She recorded the pulse and blood pressure and the presence of pallor, cold skin, sweating, confusion, restlessness, dyspnoea, and cyanosis. She recorded an electrocardiogram (ECG) and took blood for serum enzymes. She made a second visit within 72 hours, took a further ECG and blood samples and sought evidence of oedema, deep vein thrombosis, and haemoptysis. If the diagnosis was not firmly established as a result of these data, she made a further visit on the 28th day and recorded a third ECG. For patients treated in hospital most of this information was abstracted from the patient's record and copies of the ECGs were obtained.

The three clinicians in the research team assessed this information and placed each case in the following diagnostic categories. The categories used and the criteria for ECG changes were based on recommendations of the World Health Organisation. ${ }^{\text {? }}$

Definite myocardial infarction was diagnosed when there was (a) evolving injury current on ECG or a typical history with raised enzyme levels plus $Q$ waves, $S-T$ changes, $T$-wave changes, or bundle-branch block; or (b) post-mortem evidence of myocardial infarction or occlusion.

Possible myocardial infarction was diagnosed when (a) there was a typical history of prolonged chest pain associated with a nondiagnostic ECG. The serum enzyme levels might be normal or raised; or $(b)$ death was certified as due to myocardial infarction.

No myocardial infarction was diagnosed when there was an atypical history with a non-diagnostic ECG and normal serum enzyme concentrations. In other cases an alternative diagnosis became obvious after notification or the data were insufficient to permit classification.

\section{Results and comment}

There were 2771 referrals during the year, but 833 cases were not of myocardial infarction. There were 1117 definite myocardial infarctions (2.82 per 1000 population) and 821 possible myocardial infarctions (2.07 per 1000 population). The overall incidence (1938 cases) was thus 4.89 per 1000 population. The incidence of myocardial 
infarction rose with age and was slightly higher in men than in women (table $\mathrm{A}^{*}$ ).

Mortality and fatality rates-Mortality and fatality rates were based on deaths that occurred within 28 days of the onset of the attack. The overall mortality rate (deaths within 28 days per 1000 population) was $2 \cdot 5$. The overall fatality rate (deaths within 28 days per 100 attacks) was $50.5 \%$. For both sexes mortality and fatality rates increased greatly with age, and women had a more favourable experience than men (table B).

Premonitory symptoms-There has been increasing interest in the preinfarction syndrome, and this study presented an opportunity to assess its importance on a community basis. Most patients $(76 \%)$ had had at least one premonitory symptom within 90 days of their infarction, and more than a third had consulted their general practitioner in the month before the attack. Twenty per cent of patients experienced either new angina or exacerbation of existing angina. An Edinburgh survey ${ }^{8}$ found that only about 1 in 6 patients with "unstable" angina went on to develop infarction. The proportion of patients experiencing premonitory symptoms in the survey as a whole, is shown in table I.

TABLE I-Proportion of patients experiencing premonitory symptoms

\begin{tabular}{|c|c|c|c|}
\hline & $\begin{array}{l}\text { No (\%) of } \\
\text { patients }\end{array}$ & & $\begin{array}{l}\text { No }(\%) \text { of } \\
\text { patients }\end{array}$ \\
\hline $\begin{array}{l}\text { Unusual tiredness } \\
\text { Unusual breathlessness } \\
\text { Chest pain } \\
\text { Exacerbation of angina }\end{array}$ & $\begin{array}{l}384(19 \cdot 8) \\
343(17 \cdot 7) \\
217(11 \cdot 2) \\
198(10 \cdot 2)\end{array}$ & $\begin{array}{l}\text { New angina } \\
\text { Heaviness in arms } \\
\text { Unusual indigestion } \\
\text { Palpitations }\end{array}$ & $\begin{array}{r}198(10 \cdot 2) \\
171(8 \cdot 8) \\
140(7 \cdot 2) \\
83(4 \cdot 3)\end{array}$ \\
\hline
\end{tabular}

All the symptoms except angina were common complaints. Their frequency in the general population was assessed by taking a sample of 69 patients with definite myocardial infarction aged under 70 and comparing them with 69 people taken from the list of a typical general practice, matched for age and sex, but excluding those with a history of myocardial infarction or angina. These premonitory symptoms were much more common in the patients than in the controls (table II). The incidence of premonitory symptoms among the patients notified to the survey but subsequently found not to have myocardial infarction was $56 \%$. The reasons for this are not fully understood but the findings show the limitations of premonitory symptoms as diagnostic pointers.

TABLE II-Numbers of patients and controls experiencing certain general symptoms

\begin{tabular}{|c|c|c|c|}
\hline & & $\begin{array}{l}\text { Controls } \\
(n=69)\end{array}$ & $\begin{array}{l}\text { Patients with infarction } \\
\qquad(n=69)\end{array}$ \\
\hline $\begin{array}{l}\text { Unusual tiredness } \\
\text { Unusual breathlessness } \\
\text { Chest pain } \\
\text { Unusual indigestion } \\
\text { Heaviness in arms } \\
\text { Palpitations . . }\end{array}$ & $\begin{array}{ll}\because & \cdots \\
\because & \cdots \\
\because & \cdots \\
\because & \\
. & \end{array}$ & $\begin{array}{l}5 \\
3 \\
2 \\
2 \\
1 \\
1\end{array}$ & $\begin{array}{r}16 \\
11 \\
10 \\
6 \\
5 \\
2\end{array}$ \\
\hline \multicolumn{2}{|c|}{ Total No of patients: } & $8(11 \cdot 6 \%)$ & $30(43.5 \%)$ \\
\hline
\end{tabular}

Delay factors-Delay factors have been reported from various surveys ${ }^{124-69}$ and are clearly important, both for understanding fatality rates and in planning a projected service for the future. We analysed the delays only for those patients who were notified within 12 hours of the infarction, since it would have been misleading to include patients who came under medical care some days after an infarction. The figures in table III include patients treated at home and in hospital, but further analysis showed a considerable difference between them. The sequence of events was much longer in the patients who were treated at home. The general practitioner was called later and he took twice as long to get to these patients as to those he sent to hospital. The result was that both home and hospital cases came under care at about the same time, in just under three hours. The shortest delays were in the ambulance arriving and in transferring the patient to hospital.

Time of onset to death-Many patients died soon after the attack, but many of these deaths were unwitnessed so it was difficult to obtain information about them. Tracing and interviewing witnesses and

* Copies of tables A-D are available on request from the authors.
TABLE III-Median time delay periods for definite and possible cases

\begin{tabular}{|c|c|c|c|}
\hline Time periods & $\begin{array}{c}\text { Definite } \\
\text { cases }\end{array}$ & $\begin{array}{c}\text { Possible } \\
\text { cases }\end{array}$ & $\begin{array}{c}\text { All' } \\
\text { cases }\end{array}$ \\
\hline $\begin{array}{l}\text { Onset-calling GP } \\
\text { Calling GP-GP's arrival } \\
\text { GP's arrival-calling ambulance } \\
\text { Calling ambulance-ambulance's arrival } \\
\text { Ambulance's arrival-reaching hospital }\end{array}$ & $\begin{array}{l}1 \mathrm{~h} 2 \mathrm{~min} \\
29 \mathrm{~min} \\
44 \mathrm{~min} \\
13 \mathrm{~min} \\
23 \mathrm{~min}\end{array}$ & $\begin{array}{r}1 \mathrm{~h} 18 \mathrm{~min} \\
46 \mathrm{~min} \\
33 \mathrm{~min} \\
13 \mathrm{~min} \\
22 \mathrm{~min}\end{array}$ & $\begin{array}{l}1 \mathrm{~h} 11 \mathrm{~min} \\
30 \mathrm{~min} \\
44 \mathrm{~min} \\
13 \mathrm{~min} \\
22 \mathrm{~min}\end{array}$ \\
\hline Onset-reaching hospital & $2 \mathrm{~h} 51 \mathrm{~min}$ & $3 \mathrm{~h} 12 \mathrm{~min}$ & $3 \mathrm{~h} 0 \mathrm{~min}$ \\
\hline
\end{tabular}

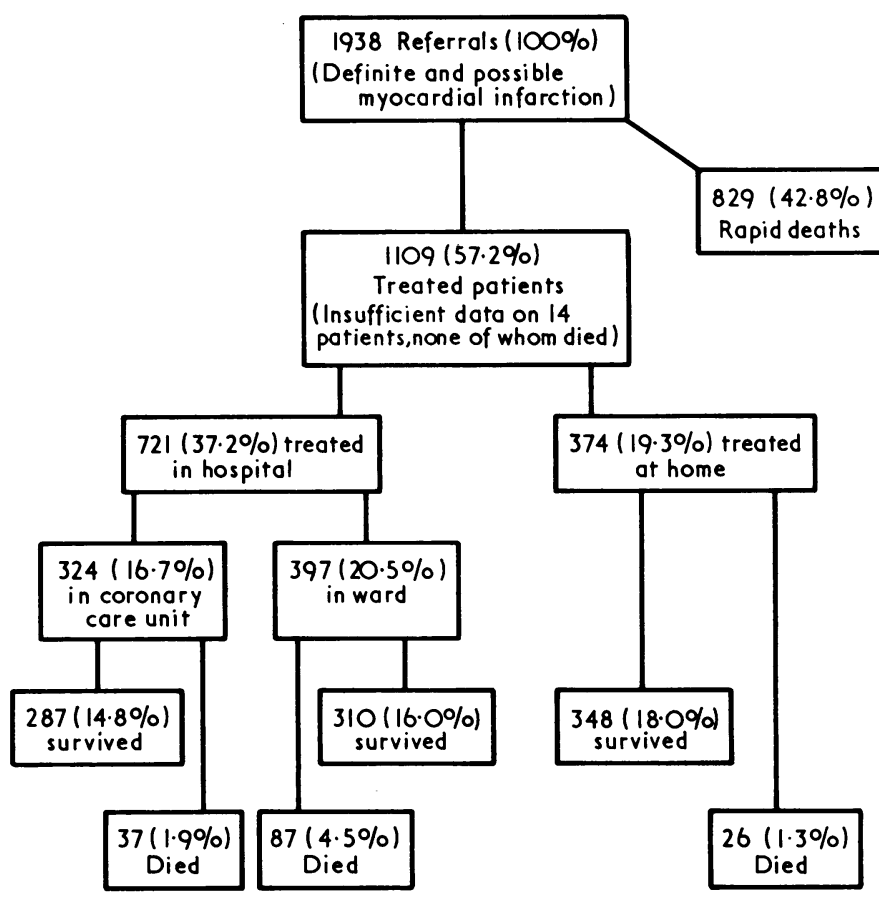

Flow chart showing what happened to the 1938 patients.

relatives was both time-consuming and embarrassing, and we decided after seven months that we had enough data. We obtained evidence about the interval to death for $78 \%$ of the deaths that had been witnessed (though we had information on $94 \%$ of witnessed deaths in those with definite infarction). Over $70 \%$ of deaths occurred within three hours of onset, the median time for patients coming under care (table C).

Place of treatment after myocardial infarction-The figure shows what happened to the 1938 patients. Eight hundred and twenty-nine patients $(42.8 \%)$ were untreated and died soon after infarction. The remainder were treated at home, in hospital wards, or in coronary care units. It was not clear in 14 cases whether the patient had been treated at home or in hospital, but none of these patients died. The group of patients treated in wards and in coronary care units included more with definite myocardial infarctions $(82.1 \%$ and $76.5 \%$ respectively) than the group treated at home $(51 \cdot 6 \%)$. Since most deaths occurred in patients with definite rather than possible myocardial infarction, the fatality rates in definite cases were analysed by place of treatment (table IV). Including those with possible myocardial infarctions would have made the difference in the crude fatality rate between home and hospital care even greater. A simple explanation of these differences would be that less severe cases had been treated at home. We attempted to assess severity, using the information gathered by the nurses at their first visit. The Peel index ${ }^{10}$ was used, modified to incorporate additional data obtained in this survey. The detailed results are given elsewhere, ${ }^{11}$ but, briefly, the modified Peel index showed no difference in severity between those treated at home and those treated in hospital. When various factors such as history, shock, rhythm changes, ECG abnormalities, etc were examined independently, they were equally distributed between home, ward, and coronary care unit cases except for age and high serum aspartate aminotransferase (SGOT) levels. Crude fatality figures were therefore standardised for these factors (table IV). Further standardisation for SGOT concentrations did not alter the figures appreciably. 
TABLE IV-Crude fatality rates (\%) in patients with definite myocardial infarction compared with aged standardised rates

\begin{tabular}{|c|c|c|c|c|c|}
\hline \multicolumn{3}{|c|}{ Place of treatment: } & Home & Ward & Coronary care unit \\
\hline \multicolumn{6}{|c|}{ Crude rates } \\
\hline$\underset{\text { Women }}{\text { Men }}$ & $\because$ & $\because$. & $\begin{array}{l}8 \cdot 3 \\
9 \cdot 7\end{array}$ & $\begin{array}{l}15 \cdot 8 \\
28 \cdot 6\end{array}$ & $\begin{array}{l}11 \cdot 8 \\
15 \cdot 7\end{array}$ \\
\hline \multicolumn{6}{|c|}{ Age-standardised rates } \\
\hline $\begin{array}{l}\text { Men } . . \\
\text { Women }\end{array}$ & $\because$ & $\because$ & $\begin{array}{l}7 \cdot 3 \\
9 \cdot 0\end{array}$ & $\begin{array}{l}14 \cdot 1 \\
26 \cdot 9\end{array}$ & $\begin{array}{l}14 \cdot 6 \\
17.6\end{array}$ \\
\hline
\end{tabular}

Sex, age, and place of treatment-It is commonly believed that there is an advantage in keeping young people, especially men, in coronary care units. This is reflected in table $\mathrm{V}$, which shows the large numbers of people under 54 who were treated in coronary care units. The figures are small but they do not show that this policy produced any convincing benefit for patients suffering definite myocardial infarction.

Myocardial infarction and social class-When compared with the total Teesside population patients in social classes I, II, and III had a higher rate of myocardial infarction than expected, while those in classes IV and $\mathrm{V}$ had a lower rate than expected. These differences were significant $(P<0.001)$ (table VI). The place of treatment, however, did not seem to be associated with social class (table D). As we expected on social grounds, more single than married people were admitted to hospital. Surprisingly, the place of treatment was not influenced by where the infarction occurred. Even when an infarction occurred in the street or at work patients were evenly distributed among the three places of treatment. Nor did the mode of onsetsudden or gradual-lead to a significant difference in place of treatment.

Effect of general practitioner's policy on care-On looking more closely at the way individual doctors managed their patients, we found that some doctors had a policy of sending almost all patients with suspected myocardial infarction to hospital, while others (the majority) adopted a mixed policy, keeping some patients at home. The age and sex distribution of the patients seemed to be the same in both groups. The years of qualification of the doctors and the size of their practices were also similar. There was a higher overall fatality rate among the 286 patients of practitioners who sent all their patients to hospital $(16.78 \%$ ) than among the 782 patients of doctors who kept some of them at home $(12 \cdot 27 \%)$, though this difference was significant only at the $10 \%$ level. In some cases the question of the general practitioner's policy did not arise because the infarction began in hospital.

\section{Discussion}

Perhaps the most remarkable achievement of this survey was the degree of co-operation achieved among the public health authorities, hospital doctors, general practitioners, and those working with them. For the first time in this country precise data were obtained on the incidence of recognised myocardial infarction in a large urban society, in both sexes and at all ages, and these could be used as a guide to possible incidence in other urban communities. Earlier surveys did not include patients over 70 years old, despite the rising incidence and fatality rates in old age; in this study those over 70 constituted $35 \%$ of all patients. Attention has previously focused on people who were considered to be of more economic value to the community. The inclusion of all age groups gives an overall incidence of 4.89 cases per 1000 population and a 28 -day fatality rate of $50.5 \%$. It is difficult to
TABLE VI-Social class and incidence of myocardial infarction

\begin{tabular}{|c|c|c|c|c|}
\hline Social class & $\begin{array}{c}\text { No }(\%) \text { with } \\
\text { definite } \\
\text { infarction }\end{array}$ & $\begin{array}{c}\text { No }(\%) \text { with } \\
\text { possible } \\
\text { infarction }\end{array}$ & Total & $\begin{array}{c}\text { Teesside (at } \\
1971 \text { census) } \\
\% \text { distribution }\end{array}$ \\
\hline $\begin{array}{c}\text { I } \\
\text { II } \\
\text { III } \\
\text { IV } \\
\text { V } \\
\text { Others }\end{array}$ & $\begin{array}{c}39(4 \cdot 7) \\
155(18 \cdot 8) \\
499(60 \cdot 5) \\
87(10.6) \\
45(5 \cdot 5)\end{array}$ & $\begin{array}{r}25(4.5) \\
84(15 \cdot 3) \\
319(57.9) \\
101(18 \cdot 3) \\
22(4 \cdot 0)\end{array}$ & $\begin{array}{r}64(14.7) \\
239(17.4) \\
818(59.4) \\
188(13.7) \\
67(4.9)\end{array}$ & $\begin{array}{r}4 \cdot 1 \\
11.5 \\
51 \cdot 1 \\
18.8 \\
12.4 \\
2.1\end{array}$ \\
\hline Total & $825(100)$ & $551(100)$ & $1376(100)^{*}$ & $100 \cdot 0$ \\
\hline
\end{tabular}

*Information on social class was available for only $71 \%$ of patients.

compare these results with those of other surveys since their figures are incomplete. When age groups can be compared there seems to be a much closer correlation with the figures from Edinburgh than with those from Oxford, which may reflect geographical variations. ${ }^{2}$

An ECG report was given to the general practitioner about each patient as an ethical safeguard rather than as a reporting service, but few doctors then changed their decision about home or hospital care. In only 50 cases did a change occur and there was usually some other reason, either medical or social, why the patient was sent to hospital. Overall, $34 \%$ of cases were managed at home by family doctors-a much higher proportion than in other reported series. ${ }^{12}$ In a recent survey in east London only $2 \%$ of patients were treated at home. ${ }^{6}$

Roughly one-third of patients were treated at home, one-third on ordinary hospital wards, and one-third in coronary care units, a fortuitous division for comparison. More patients with definite myocardial infarction were treated on the ward and in coronary care units than at home, and most of the deaths occurred within this category. Age-standardised fatality rates for definite cases were much lower for patients treated at home than for those treated in hospital. The higher fatality rate in both wards and coronary care units might have been explained by more severe cases being treated in hospital, but this did not appear to be so. ${ }^{11}$

We did two further checks to exclude possible errors. Firstly, some patients who died soon after onset might have qualified as home-treated patients if general practitioners had been treating them at home before death and had failed to notify them. A detailed search showed a few such cases but not enough to alter the fatality rates materially. Secondly, our comparison of cases was based on the findings at the time of first full clinical assessment, including ECG, which took place some time after notification. In the interval some patients died, so that there were 64 more notifications than assessments. Sixty-three of these patients had been notified for hospital care and 15 to 30 died in the ambulance itself. Though these cases did alter the crude fatality rate, when the figures were standardised again for age there was no significant difference in the fatality rates, which still showed an advantage for the home-treated group of patients. This confirms the trend of other surveys. ${ }^{2}{ }^{3}$

An analysis during the first half of the survey of those deaths due to definite myocardial infarction that were witnessed gave complete information for $94 \%$ of cases. Altogether $56.6 \%$ of these patients had died suddenly and a further $22 \%$ died within the next two hours.

The median time for patients coming under care was just

TABLE $\mathrm{V}-$ Fatality according to age and place of treatment in those with definite myocardial infarction

\begin{tabular}{|c|c|c|c|c|c|c|c|c|}
\hline \multirow{2}{*}{$\underset{\text { (years) }}{\mathrm{Age}}$} & \multicolumn{2}{|c|}{ Home } & \multicolumn{2}{|c|}{ Ward } & \multicolumn{2}{|c|}{ Coronary care unit } & \multicolumn{2}{|c|}{ Total } \\
\hline & $\begin{array}{c}\text { No of } \\
\text { patients }\end{array}$ & $\begin{array}{l}\text { No (\%) of } \\
\text { deaths }\end{array}$ & $\begin{array}{c}\text { No of } \\
\text { patients }\end{array}$ & $\begin{array}{l}\text { No (\%) of } \\
\text { deaths }\end{array}$ & $\begin{array}{c}\text { No of } \\
\text { patients }\end{array}$ & $\begin{array}{l}\text { No (\%) of } \\
\text { deaths }\end{array}$ & $\begin{array}{c}\text { No of } \\
\text { patients }\end{array}$ & $\begin{array}{c}\text { No (\%) of } \\
\text { deaths }\end{array}$ \\
\hline $\begin{array}{c}45-54 \\
55-64 \\
65-74 \\
\geqslant 75 \\
\end{array}$ & $\begin{array}{l}37 \\
53 \\
71 \\
32 \\
\end{array}$ & $\begin{array}{ll}2 & (5.4) \\
3 & (5.7) \\
6(8.5) \\
6(18.8) \\
\end{array}$ & $\begin{array}{r}52 \\
91 \\
102 \\
81 \\
\end{array}$ & $\begin{array}{c}5(9 \cdot 6) \\
10(11 \cdot 0) \\
25(24 \cdot 5) \\
21(25 \cdot 9) \\
\end{array}$ & $\begin{array}{l}92 \\
98 \\
47 \\
11\end{array}$ & $\begin{array}{c}9(9 \cdot 8) \\
10(10 \cdot 2) \\
10(21 \cdot 3) \\
3(27 \cdot 3)\end{array}$ & $\begin{array}{l}181 \\
242 \\
220 \\
124 \\
\end{array}$ & $\begin{array}{l}16 \\
23 \\
41 \\
30 \\
\end{array}$ \\
\hline Total & 193 & $17(8 \cdot 8)$ & 326 & $61(18 \cdot 7)$ & 248 & $32(12.9)$ & 767 & $110(14 \cdot 3)$ \\
\hline
\end{tabular}


under three hours, both for patients admitted to hospital and for those kept at home. This was similar to times reported in other surveys-for example, from Edinburgh ${ }^{1}$ and Doncaster ${ }^{5}$ - though the evidence from Belfast ${ }^{413}$ shows that the presence of a coronary ambulance in the community, with its attendant publicity, leads to earlier notification of cases by patients and their families.

There was a curious difference in the speed of notification between those patients whom the general practitioner subsequently sent into hospital and those he kept at home. On average, the call to the doctor for patients who subsequently went to hospital was put in half an hour earlier, and, once he had been called, the general practitioner reached the patient twice as quickly. This difference could not be explained by whether the onset was sudden or gradual or whether the main symptom was pain, syncope, dyspnoea, or dysrhythmia. Nor was there any significant difference in severity between the two groups of patients. The difference may have been related to a patient's pain threshold or the way in which a patient or family reacted to a crisis. If a patient responded with alarm or panic then the doctor might be notified more quickly. The degree of urgency would be transmitted to the doctor, who would go quickly to the patient. If, on the other hand, a patient did not feel the attack to be threatening he might well delay calling the doctor or request a visit conveying no sense of urgency. Under such circumstances, the doctor took twice as long to reach the patient. If this hypothesis were correct, it could be argued that such an anxious group of patients being sent to hospital might be more prone to rhythm disturbances and cardiac arrest, though a small inquiry into the anxiety state of patients treated at home and in hospital, and reported elsewhere, ${ }^{14}$ showed no definite difference on formal testing.

\section{REDEFINING ROLE OF CORONARY CARE UNIT}

The data suggest that the role of the coronary care unit in the community needs to be redefined. Patients who have survived for a few hours after the onset of myocardial infarction seem to do as well, if not better, if they are left at home. This study does not deny the potential benefit of efficient coronary care to patients who have just had a myocardial infarct, but merely emphasises that, as used at present, coronary care units contribute little to improving fatality rates in the patients who survive long enough to reach them. In view of the high early fatality rate which is already known in this condition and which this study further describes, it seems unlikely that it will be possible to speed up admission sufficiently to give patients the potential benefit of coronary care units. There is also the possibility that rapid transport of these patients to hospital may be deleterious. It would seem more logical that resuscitative facilities should be provided for patients in their homes, though the cost and feasibility of such a scheme would have to be assessed.

The urgency of reaching patients is not always appreciated by general practitioners, and guidelines have been proposed to try to clarify the problem. ${ }^{12}{ }^{15}$ The general practitioner must be prepared to give continuous cover, particularly when he is called soon after the attack. There is evidence that moving ill and shocked patients will alter pulse and blood pressure. ${ }^{16}$ During the Teesside survey 15 to 30 patients died in the ambulance. Despite keeping careful records it was often difficult to know precisely when a patient died under these circumstances. Others died after transfer to hospital but before being formally admitted to a ward or a coronary care unit. Our results seem to show that it is hazardous to move patients to hospital, but if this must be done for medical reasons then it should be done under skilled supervision, with resuscitative equipment available.

\section{EDUCATIONAL PROGRAMME NEEDED}

With our present knowledge we believe that intensive care must begin in a patient's home, but we do not yet know how general practitioners will rise to this challenge. There must be an educational programme for both doctors and the public to help them to accept home care as being the correct treatment in many cases. Myocardial infarction is a serious condition, and deaths will occur at home just as they do in hospital. A possible solution would be for properly trained groups of general practitioners to man suitably equipped vans, and projects of this kind have begun in some places. Another solution would be for similar vans manned by medical staff and based on district hospitals to go to patients' homes. These teams would join the general practitioner and a joint decision would be made about subsequent care and responsibility, once the patient's condition had been stabilised.

We recognise that our figures can be criticised, but it may never be possible to collect completely satisfactory information in a community survey of this size. Nevertheless, it seems reasonable to conclude that under the present circumstances, for those who survive to come under care, home care is as good if not better than hospital treatment. We believe that fatality rates can be considered only on a community basis, and, though physicians often quote success in intensive care units for certain individuals, this success must be balanced against possible harm in moving ill and shocked patients to a hospital.

The community approach to the care of patients after myocardial infarction, involving hospitals, general practitioners, and other helpers, seems to be the correct one. As further advances are made in understanding coronary care so the programme may need to be modified. As with the treatment of other medical conditions, home and hospital care should be seen to be complementary and not as alternatives.

We are indebted to all the nurses and doctors on Teesside who contributed by collecting information for this survey, and to their secretaries who notified the cases. We would especially like to thank sisters E Young, C Kirby, and C Smith and staff nurse C Wylie, who worked more than full-time on the project; $\mathrm{Mr} \mathrm{O}$ Downing, who co-ordinated the routine work so effectively; Mrs S Hyde and $\mathrm{Mr} \mathrm{M}$ Byrne, who, with Mrs J Garlick, analysed the data and prepared a preliminary report; $\mathrm{Mr} \mathrm{K}$ Coates, research officer, and other members of the Teesside Health Department, who gave invaluable help; Dr E Walton, the late Dr S Ray, and staff for their pathology services; Mr F E Harper, biochemist; Mr M Sheffield, Coroner; Mr E Gifford, chief ambulance officer; and many others who helped in vital ways. We also thank Professor J N Morris, Professor D G Julian, Dr M Oliver, and Dr H Tunstall Pedoe for their valuable help in the planning stages.

The research was supported by a generous grant from the Newcastle Regional Hospital Board and completed with extensive help from the Teesside County Borough Council.

Copies of the unpublished tables may be obtained from $\operatorname{Dr} A$ Colling, Postgraduate Centre, North Tees General Hospital, Stockton, Teesside.

\section{References}

1 Armstrong, A, et al, British Heart fournal, 1972, 34, 67.

2 Kinlen, L J, British Heart fournal, 1973, 35, 616.

3 Mather, H G, British Medical fournal, 1971, 3, 334.

4 Pantridge, J F, and Geddes, J S, Lancet, 1967, 2, 271.

5 Smyllie, H C, Taylor, M P, and Cuninghame-Green, R A, British Medical fournal, 1972, 1, 31 .

6 Pedoe, H T, Lancet, 1975, 2, 833.

7 World Health Organisation, Hypertension and Coronary Heart Disease, Technical Report Series No 168. Geneva, WHO, 1959.

${ }^{8}$ Fulton, M, et al, Lancet, 1972, 1, 860

9 Sandler, G, and Pistevos, A, British Heart Fournal, 1972, 34, 1283.

10 Peel, A A F, et al, British Heart fournal, 1962, 24, 745.

11 Dellipiani, A W, et al, in press.

12 Colling, W A, British Medical fournal, 1974, 1, 559.

13 Adgey, A A J, et al, Lancet, 1971, 2, 501.

14 Dellipiani, A W, et al, British Heart fournal, 1976, 38, 752.

15 Council Report, fournal of the Royal College of General Practitioners, $1974,24,829$.

16 Waddell, G, British Medical fournal, 1975, 2, 417. 